\title{
Digital marketing in the SPA-resort product promoting
}

\author{
Voinova Ianina ${ }^{1, *}$ \\ ${ }^{1}$ Sochi State University, Sochi, Russia
}

\begin{abstract}
Digital marketing technologies create new ways for driving customers in spa-product purchasing, providing feedbacks and endorsements due to new methods of communication, supporting and reinforcing Spa-resort product producers and distributors promises. Actually, at this time resort market has no effective and united strategy for SPA-resort product promotion and sales, which has to be based on modern digital marketing instruments. The review of digital SPA-resort market in Black Sea resorts and Caucasian Spas areas revealed the lack of coordination between providers of natural curative resources, tourist's accommodation means, healthcare facilities and travel organizers. Ignoring the specifics of SPA-resort product and uniqueness of its nature in its promotion and merchandising causes the drop-in sales because of the decrease in consumer interest and lack of information about variety of product benefits for health resumption. Thus, recommendations and suggestions about possible ways of joining efforts in SPA-product rout-to market with use of digital marketing technologies would show a large return to the resort industry in a long-term period.
\end{abstract}

\section{The SPA-resort product as an object of e-commerce}

\subsection{Overview of SPA-resort product}

SPA-resort product is a complicated mixture of technologically varied services, provided by local resort hospitality and balneary organizations.

The product core is a natural mineral resource of the resort area. Its chemical nature and physical action on human's organism are define the medical specialization of healthcare resorts. For example, Sochi's treating springs Matsesta [1] fits well for itching associated with skin and musculoskeletal system diseases, gynecological disorders. Narzan is a mineral water, which is used in Kislovodsk resort for digestive organs therapy. Health resort polyclinic is another important element in resort service, which provides traveler with medical advice. Licensed enterprises of hospitality industry can also provide tourist with different SPA-services [2].

The following figure 1 is presented the general SPA-resort product structure (see Fig. $1)$.

\footnotetext{
* Corresponding author: forexceed@gmail.com
} 


\begin{tabular}{|c|l|}
\hline SPA-therapy & $\begin{array}{l}\text { - Delivered by resort balnearies } \\
\text { - Based on resort natural mineral resorces }\end{array}$ \\
\hline SPA-services & $\begin{array}{l}\text { - SPA-circuit in hotel or sanatoria } \\
\text { - Assume rehabilitation and cosmetis effect }\end{array}$ \\
\hline $\begin{array}{c}\text { Accommodation and } \\
\text { catering services }\end{array}$ & $\begin{array}{l}\text { - Provides by SPA-hotels } \\
\text { Provides by therapeutic facilities } \\
\text { (sanatoria) }\end{array}$ \\
\hline
\end{tabular}

Fig. 1. The SPA-product structure (local resort aspect).

As can been seen from the above SPA-resort product is designed by balnearies, which is exploiting the mineral resources, resort polyclinics and laboratories, licensed enterprises of hospitality industry.

Balnearies are situated close to the production field, where resources are extracted. They consist of several departments: administrative and managerial staff, medical department, halls with bath cabins or showers. Medical department staff includes doctors and nurses. They involved in the drawing up of a sanatorium and health resort card forms and in the baths release. One of the main problems in resort therapy is the transport. SPA-hotels and sanatoria have to resolve the problem how to take tourists to the balneary. This organizations have to maintain buses and all the garage staff. It is possible to lease the bus, but is it also associated with extra cost. There is common rule, that at least one nurse from the sanatoria has to escort the group of tourists to guarantee their safety ang well-being. Due to several difficulties in the providing SPA-resort treatment in the balnearies, this organizations should develop a system of stimulation for contracted clients presided by sanatoria and hotels.

It is common practice of the latest years that sanatoria and SPA-hotels try to organize SPA-treatment without balnearies services. They include alternative SPA-methods, which is based on internal facilities. But often this moves lead to deficiency of treatment program. This is why the problem of balancing balnearies and SPA-hotels is being actual. Positive aspect is a possibility to find the balance of interests using the cooperation principles.

\subsection{The national resort market structure in Russia}

SPA-resort customer is a special needs category of people, who are looking for resort treatment, recovery and rehabilitation. Thus, to get SPA-resort product is possible by visiting balneotherapeutic health resort areas. This kind of product consists on: basic services (hospitality, resort treatment) and associated services (catering, transportation, animation, excursion, shopping and others). The following Table 1 presents the national resort market structure and its member's treatment functions.

Product development could be proceeding by several ways. It could be done by tour operator's companies for commission fee or by SPA-resort organizations without any assistance. In the first case market intermediary has a middle position between sanatoriumand-SPA resort organizations and clients [3]. The aims of tour operator are to predict consumer wishes, to present the product in the right way and support clients in the travelling prosses. Direct sale is more profitable for resort hospitality and balneary organizations and release them from commission fee payment. 
Table 1. The national resort market structure (treatment-functional aspect).

\begin{tabular}{|l|l|l|}
\hline \multicolumn{1}{|c|}{ Market position } & $\begin{array}{l}\text { Corporate } \\
\text { identity }\end{array}$ & \multicolumn{1}{|c|}{ Health resort treatment function } \\
\hline $\begin{array}{l}\text { Autonomic providers of } \\
\text { based on resort mineral } \\
\text { resources therapeutic } \\
\text { services }\end{array}$ & $\begin{array}{l}\text { Resort } \\
\text { balneary }\end{array}$ & $\begin{array}{l}\text { Dispensation of sulfurated hydrogen, radon, iodine- } \\
\text { bromine, Narzan baths and douches }\end{array}$ \\
\hline $\begin{array}{l}\text { Rud-bath } \\
\text { balneary }\end{array}$ & Mineral mud baths, mud poultice applications, mud wraps \\
\hline $\begin{array}{l}\text { sicensed to medicine } \\
\text { means of tourists }\end{array}$ & Sanatoria & $\begin{array}{l}\text { Laboratory section, functional diagnostics section, } \\
\text { instrumental physiotherapy, physiotherapeutic procedures, } \\
\text { medical aesthetics, ozone therapy, inhaling, } \\
\text { balneotherapy: carbon dioxide, gas-bubble, naphthalan } \\
\text { baths, duches, colon hydrotherapy. }\end{array}$ \\
\cline { 2 - 4 } & SPA-hotels & $\begin{array}{l}\text { Beauty medicine, massage therapy, cryotherapy, } \\
\text { phytoterapy. }\end{array}$ \\
\hline Healthcare facilities & $\begin{array}{l}\text { Health } \\
\text { resort } \\
\text { polyclinic } \\
\text { and } \\
\text { laboratories }\end{array}$ & \begin{tabular}{l} 
Laboratory section, specialized medical consultation \\
\hline
\end{tabular} \\
\hline
\end{tabular}

\section{Digital marketing technologies in SPA-resort industry}

\subsection{Digital technologies in self-marketing and business marketing cooperation}

When the prosses of product development is finished, marketing divisions starts the consumer franchise building. In this prosses SPA-resort organizations can configure with self-marketing or business marketing cooperation.

In the former case (self-marketing) the process looks like the separation of balnearies and SPA-hotels and sanatoria efforts from other market participants in advancing customer engagement. There are several ways to distribute product: inbound sales or outbound sales. Inbound sale is a kind of personal on-line or off-line sale. It based on consuming interest, which is a result of surfing the Internet, word-of-mouth marketing, presented by medicine advise of doctor in municipal polyclinic or friend's recommendations. SPA-resort organizations can 3 ulfil the orders to the bulk quantity sanatorium vouchers on a regular contractual relationship with companies and corporations. Outbound sales assume email marketing, SMS, telephone advertising to inform buyers and to sell services. Each voucher sale contracted individually with consumer or company. After prepayment or settle in total commercial service of SPA-resort organization is booked rooms on fixed dates.

It is possible to conclude, that self-marketing prosses consists of several activities in digital area [4], which represented on the scheme below (see Fig. 2). 


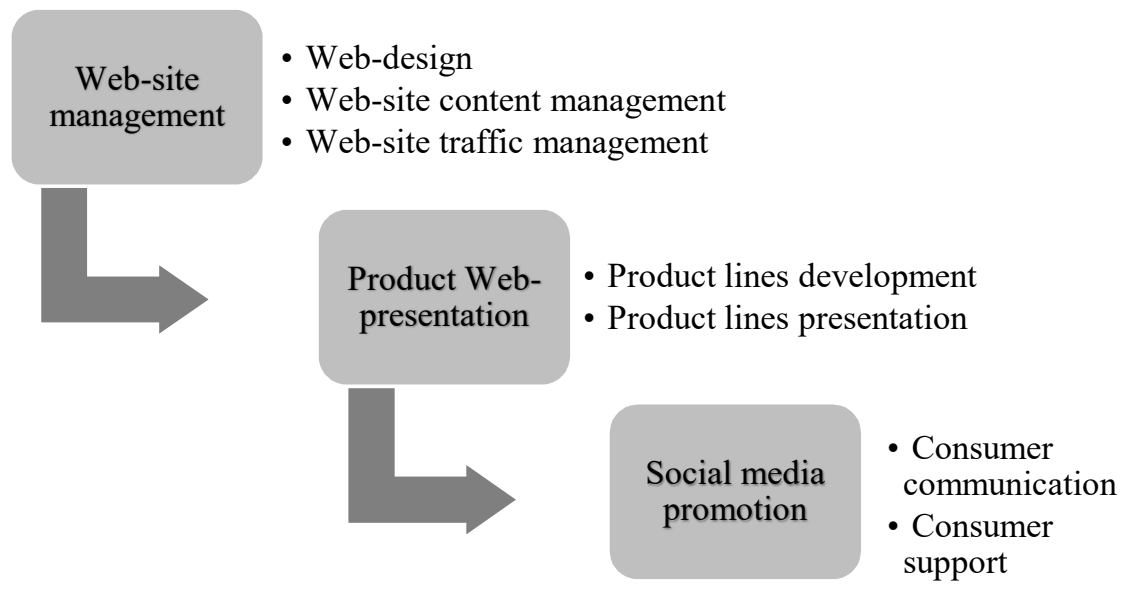

Fig.2. Product marketing by SPA-services providers.

Web-site management starts from web-design. There are some common rules how corporative web-site should be built. It has to be easy understandable and superbly functional. Template of Website's main page navigation has to be presented by several levels. Most commonly to 4ulfil first level with company summary, treatment specification, medical fee schedule or price-list, promotional deals (discounting), virtual tour, contact details.

Web-site content needs to be managed too. It has to be effective in converting visitor into consumer. Main aim of unique content is to grip the attention of audience. If visitors' average time on site is more than 2 minutes that chances to product distribution is growing faster. Publishing on website video materials is useful to present product better.

Web-site traffic management includes variety of directed on audience attraction actions. To reach this aim is possible due to using Google, Yandex and others advertising systems. To measure the quantity of visitors, time of surfing the site, most interesting section is possible with analytics systems: Google analytics, Yandex metrics.

For advertising and distribution purposes start-page must be constructed as a landing page with pressing product presentation. Experience has proven that it is better to present products as a clickable image, which lead web-visitor to next level to get to know with services in details. It is possible to add Usually the name of the product oriented on customer needs. In product name it is necessary to use gender orientated information and medical diagnosis. Customer should clearly identify particular SPA-product is to be designed to satisfy pronounced needs. As an example, it is worth mentioning Matsesta SPA-resort products, named as: "Men's strength", "Female protection", "Flexibility of movements", "Clear skin", "Post-burn recovery", "Unlabored breathing", «Rhythm of healthy heart" and others. Actually, all these products include Matsesta baths and supplementary services. Technologically all these products are looking similar. Different names in this situation help to push client to buy product which meet his or her requirements.

Graphic charter and web-design depend on the consumers interaction strategy [5]. Websites often use social-media buttons such as VK, OK, Fb, Instagram and YouTube to gain more followers. Each active subscriber is a valuable asset for advertising dissemination. While travelling and posting new photos, short video stories in profile lots of blogger's followers become acquainted with company product and over-the-counter SPA-services. Reposting company advertorials, marking unique hashtags could also attract attention of new auditoria. In such way is possible to extend variety of potential customers. 
Communication prosses is arranged by live-chat panel and free federal hot-line number 8$800-* * *_{-} * *_{-} * *$, which is hold in store for responding on personal questions.

There are several ways of communicate lining. Company marketing division customize chat-robot to reply common questions. Clients of SPA-product, who is going to the resort on their own initiative, due to its medical specific require individual consultation with health staff. They are needed such specialist's advice for choosing and ordering the most effective program of resort therapy. So, SPA-hotels or sanatoria besides marketing staff have to provide consumers with professional medical advice especially it those cases when tourists have a wish to come for treatment without sanatorium and resort card. It is only doctor who can exactly define the period for tests and health screening.

Business digital marketing cooperation assume joining of SPA-resort organizations and market intermediary companies' efforts, for example Booking.com, TripAdvisor, Trivago, Biblio-Globus and others in distribution [6]. The collaboration is paid for each booking action in fixed fee.

In the latter case resort hotels, sanatoria and balnearies pool efforts to achieve a great deal in resort SPA-product distribution, which consistently include mineral resources of balneotherapeutic health resort and treatment procedures in sanatoria and hotels due to provide customer with effective and fine resort treatment.

Cooperation is based on merchandising multi-SPA-product and partner interacting of resort balnearies, hotels and sanatoria. This collaboration considers $10 \%$ or $15 \%$ commission fee to the corporate seller. It is possible due to using the same booking system, for example TravelLine extranet. SPA-product in such case is presented by dual-product: hotel or sanatoria product and balneary product. Enhancing the effectiveness of SPA-resort product sales will be possible due to networking of market transactors.

The analysis of website advertising budgets showed that this amount is about $250-300 €$ per month and influx of 40000 visitors. This sum is spent on pay-per-click advertising (Google and Yandex advertising services). Conversion of traffic flow and sales is low: it is one sale in 800 visitors. So, it is possible to conclude that site's interfaces don't engage visitors, don't catch their attention for long and don't allow high sales.

The sales prosses, which unite all market operators is shown below (see Fig. 3).



Fig. 3. Business marketing cooperation scheme.

In the latter case resort hotels, sanatoria and balnearies pool efforts to achieve a great deal in resort SPA-product distribution, which include mineral resources of balneotherapeutic health resort and treatment procedures in sanatoria and hotels. 
Cooperation is based on merchandising multi-SPA-product and partner interacting of resort balnearies, hotels and sanatoria. This collaboration considers fixed commission fee to the corporate seller. It is possible due to using the same booking system, for example TravelLine extranet. SPA-product in such case is presented by dual-product: hotel or sanatoria product and balneary product.

The sales prosses in such case is shown on figure 4 .

Customer inquiry (termed diagnosis)

Advertising

Directing to the Web-site

Customer's claim

Hot-line, live-

chat, e-mail

consultation

Selling

transaction

Fig. 4. Sales tunnel of SPA-resort product.

Sales tunnel of SPA-resort product consists of several stages [7]. They are:

1. customer inquiry is defined by several ways. First of them is a medical advice in the polyclinic or hospital at the customer's house. Resort treatment is possible to divide on two types: rehabilitation (after surgery or professional accident) and recovering (recreation combined with resort treatment). Rehabilitation suppose medical referral to the resort, which based on variety of tests and health screening. In this case customer is wellinformed. Actually, questions may be linked to hospitality conditions, catering, special services, excursions and so on. All these answers can be given by specialists from marketing department. If the client acts on impulse the questions might be more special and needed qualitative answer of medical specialist. So, its better to involve sanatoria or balneary medical staff in such situations.

2. When customer is well-informed about his treatment needs the prosses of choosing the right sanatoria or SPA-hotel is beginning. There are several ways to find the appropriate variant. The main one is a price. Another one is a quality of accommodation and catering. For understanding this customer can observe the comments of former buyers. That's why observing the comments and responsing the incident are very important. All abuses need to be answered (e-wom) [8]. If comment is full of details in descriptions the more chances, that this message will be harmful for place of accommodation. Specialist should ask what was the problem. If this problem is real it is better to apologize and make a discount or suggest any other form of reparation. The best solution of the conflict is to satisfy customer needs and turn to delete abuse.

The quantity of web-site visitors depends on the contextually targeted advertising. That why this activity requires great attention and highly technically trained professional.

3. After formulating the search query Search Engine presents the most relevant website link. Clicking the link customer join the web-site of the company which has to be organized to sell the product. Up till now most of web-sites doesn't with no online payment option. They work as a source of information, but not like a sales tool. 
4. Next stage is a customer's claim. If web-site hasn't online booking and payment option customer can claim using the traditional ways: by telephone, live-chat or e-mail.

5. The manager prepares the contract for services and sent an invoice to the client. After paying the bill, the room is booked for fixed in agreement dates.

\section{Conclusions}

The undertaken research allowed to draw some conclusions. SPA-resort organizations in digital area work separately [9]. Some of them use modern digital technologies, but with rather low efficiency. Enterprises in SPA-resort business prune the budget in digital sphere and use up outdated methods of selling the SPA-resort product. That's why it is hard to drive customer engagement with using digital marketing instruments. Incoherence makes for fail in digital marketing [10].

For easing of the situation is needed to mount a sharing with success in digital sphere between all members of SPA-resort market on constant base. It is important to teach personnel of marketing departments how to use digital technologies to raise the distribution to reach the sustainable long-term effect in this specialized business.

\section{References}

1. Matsesta Homepage, http://matsesta.info, last accessed 2020/02/20.

2. D. Dryglas, M. Salamaga, Journal of Destination Marketing \& Management 9, 234-246 (2018)

3. A. Sharma, S. Sharma, M. Chaudhary, Tourism Management 79, 104078 (2020)

4. L. Busca, L. Bertrandias, Journal of Interactive Marketing 49, 1-19 (2020)

5. P. De Pelsmacker, S. van Tilburg; C. Holthof, International Journal of Hospitality Management, 72, 47-55 (2018)

6. A. Ahani, M. Nilashi, O. Ibrahim, L. Sanzogni, International Journal of Hospitality Management 80, 52-77 (2019)

7. Y. K. Dwivedi, N. P. Rana, E. L. Slade, N. Singh, H. Kizgin: Journal of Retailing and Consumer Services 53, 101909 (2020)

8. Y. Bu, J. Parkinson, P. Thaichon, Australasian Marketing Journal (2020)

9. P.K. Kannan, H. "Alice" Li,International Journal of Research in Marketing 34(1), $22-45$ (2017)

10. A. Goldfarb, C. Tucker, Chapter 5. Digital marketing. Handbook of the Economics of Marketing. 1, 259-290 (2019) 